\title{
Rancang Bangun Solar Charger dengan Maximum Power Point Tracking (MPPT) dan Kontrol Proportional Integral Derivative (PID) Untuk Pengisian Baterai Lithium-Ion
}

\author{
Novie Ayub Windarko ${ }^{1}$, Irianto $^{2}$, Agus Tami $^{3}$ \\ Teknik Elektro Industri, Departemen Elektro, Politeknik Elektronika Negeri Surabaya ${ }^{1}$ \\ Teknik Elektro Industri, Departemen Elektro, Politeknik Elektronika Negeri Surabaya ${ }^{2}$ \\ Teknik Elektro Industri, Departemen Elektro, Politeknik Elektronika Negeri Surabaya ${ }^{3}$ \\ ayub@pens.ac.id ${ }^{1}$, irianto@pens.ac.id ${ }^{2}$, *agus.tami.0004@gmail.com ${ }^{3}$
}

\begin{abstract}
Solar charger is a tool to charge battery energy by using solar panel. Generally, the process of battery charging using solar charger still uses the Constant Current-Constant Voltage method. The application of Constant Current-Constant Voltage method on solar charger has a flaw on Constant Current mode, when the solar panels is not able to reach the specified current, then a voltage drop will occur so that there is no charging on the battery. The problem faced by using solar charger is the fluctuating output of solar panels is influenced by several parameters, those are temperature, light intensity, and the given load. As of that a control is needed which can track so that the solar panel output can be maximized for battery charging. In this research, by using buck converter as solar charger and MPPT modified incremental conductance as the method in order to search the maximum output power of the solar panel and PID analytical method is used to produce constant output voltage of converter for Li-Ion battery charging. Based on maximum tracking of MPPT modified incremental conductance method at $1000 \mathrm{~W} / \mathrm{m} 2$ Irradiance with a duty cycle of $70 \%$ produces $99.53 \mathrm{~W}$ of maximum power output of buck converter, 12.52 V of output voltage of buck converter and 7.95A current. PID Control with parameter values such as $K P=7.8 \mathrm{KI}=50000$, and $\mathrm{KD}=0.000304$ is used to get constant output voltage of $12.6 \mathrm{~V}$ of buck converter.
\end{abstract}

Keywords: Li-Ion Battery, Buck Converter, MPPT Modified Incremental Conductance Method, Analytical PID, Solar Charger

\section{INTISARI}

Solar charger merupakan alat untuk mengisi energi baterai dengan memanfaatkan panel surya. Pada umumnya, proses pengisian baterai dengan solar charger masih menggunakan metode Constant Current-Constant Voltage. Penerapan metode Constant Current-Constant Voltage pada solar charger memiliki kelemahan yaitu pada mode Constant Current, Saat panel surya tidak mampu mencapai arus yang ditentukan maka akan terjadi drop tegangan sehingga tidak terjadi pengisian pada baterai. Permasalahan yang dihadapi dari penggunaan solar charger adalah keluaran panel surya yang fluktuatif dipengaruhi oleh beberapa parameter yaitu suhu, intensitas cahaya dan pembebanan yang diberikan. Sehingga diperlukan sebuah kontrol yang dapat tracking agar keluaran panel surya dapat dimaksimalkan untuk melakukan pengisian baterai. Pada penelitian ini memanfaatkan buck converter sebagai solar charger serta metode yang digunakan yaitu MPPT modified incremental conductance bertujuan untuk mencari daya maksimum keluaran panel surya dan PID metode analitik untuk menghasilkan tegangan keluaran konverter yang konstan untuk pengisian baterai Li-Ion. Dari hasil tracking maksimum MPPT metode modified incremental conductance pada iradiasi $1000 \mathrm{~W} / \mathrm{m}^{2}$ dengan duty cycle $70 \%$ menghasilkan keluaran daya maksimum buck converter 99,53W serta tegangan keluaran buck converter 12,52V dan arus 7,95A. Kontrol PID dengan nilai parameter $\mathrm{KP}=7,8, \mathrm{KI}=50000$, dan $\mathrm{KD}=0,000304$ digunakan untuk mendapatkan tegangan keluaran buck converter konstan sebesar $12,6 \mathrm{~V}$.

Kata kunci: Baterai Li-Ion, Buck Converter, MPPT Metode Modified Incremental Conductance, PID Analitik, Solar Charger

\section{PENDAhUluAN}

Solar charger merupakan alat pengisian baterai sampai pada rating tegangan yang ditentukan dengan menggunakan sumber panel surya. Pada umumnya penggunaan baterai yang umum digunakan saat ini adalah untuk kendaraan bermotor. 
Selama ini pengisian baterai masih menggunakan sumber dari jala-jala PLN. Namun dikarenakan perkembangan energi alternatif yang cukup pesat, sehingga dapat dilakukan pemanfaatan energi alternatif sebagai pengisian pada baterai yaitu energi dari tenaga surya. Energi ini merupakan salah satu alternatif yang baik untuk masa kini dan masa yang akan mendatang. Dimana alat yang digunakan untuk mengkonversikan energi surya atau cahaya menjadi energi listrik adalah panel surya[8].

Pemanfaatan solar panel sebagai pembangkitan energi listrik masih memerlukan sebuah konverter. Hal ini dikarenakan hasil output dari panel surya masih fluktuatif. Dengan adanya konverter tipe buck converter, bertujuan sebagai penurun level tegangan sumber (input) dan juga ditambahkan kontrol MPPT metode modified incremental conductance agar hasil output konverter dapat memaksimalkan input konverter keluaran panel surya serta sebuah kontrol PID yang mengkonstankan tegangan output konverter sebesar tegangan maksimum chargig baterai sesuai rating sehingga dapat digunakan untuk melakukan pengisian sebuah penyimpan energi yang selanjutnya dapat digunakan sebagai supply energi listrik pada kehidupan sehari hari.

Sehingga pada penelitian ini dibuat sebuah sistem dengan memanfaatkan energi hasil panel surya yang kemudian energi tersebut disimpan pada sebuah storage tegangan dan arusnya dimaksimalkan terlebih dahulu oleh sebuah konverter bertipe buck penurun tegangan memanfaatkan perpaduan MPPT dan kontrol PID.

\section{LANDASAN TEORI}

\section{A. Buck Converter}

Buck Converter adalah salah satu tipe Converter $D C$ ke $D C$ yang menghasilkan tegangan output yang nilainya lebih kecil dari tegangan input.

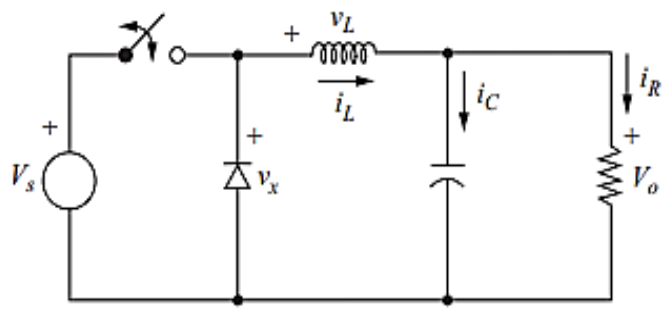

Gambar 1. Rangkaian Buck Converter

Dari Gambar 1 dapat diketahui bahwa rangkaian terdiri atas satu saklar aktif berupa switching dan juga terdapat saklar pasif (dioda), dan induktor serta kapasitor adalah sebuah pembatas keluarannya. Penggunaan dioda sebagai saklar pasif dapat digunakan sebuah saklar aktif sehingga adanya susut daya bisa dikurangi[1].

\section{B. Baterai Li-Ion}

Baterai Lithium-ion merupakan salah satu jenis baterai rechargeable yang digunakan pada berbagai peralatan elektronik terutama yang berjenis portable[7].

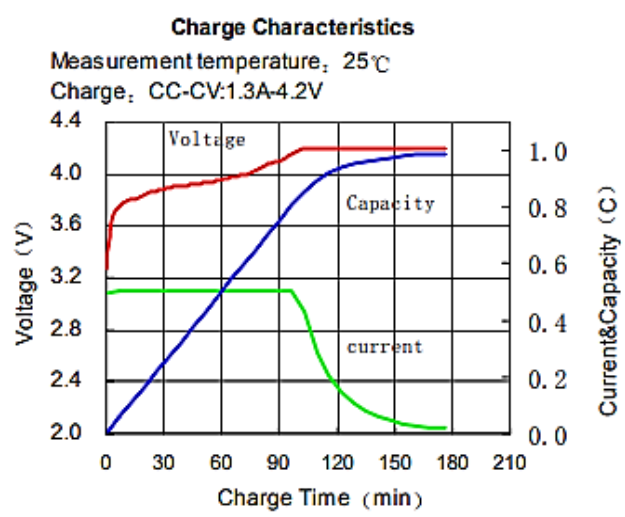

Gambar 2. Karakteristik Pengisian Baterai Li-Ion

Dari Gambar 2 dapat diketahui bahwa prinsip kerja dari $C C-C V$ yaitu mula mula arus pengisian ditahan konstan, dan lama kelamaan akan berefek pada tegangan sel baterai yang semakin naik. Saat tegangan pengisian sudah mencapai tegangan maksimum pengisian sesuai rating pada data sheet maka tegangan akan dikonstankan sebesar tegangan pengisian tersebut. Dengan tujuan agar tidak merusak daripada sel baterai dan konstannya tegangan yang diberikan maka baterai akan terisi sehingga akan terjadi penurunan pada nilai arus pengisiannya dikarenakan semakin sedikitnya selisih antara tegangan sumber pengisian dan baterai. Baterai dikatakan penuh saat tegangan pengisian sudah mencapai tegangan maksimum baterai dan arus pengisian nol[2].

\section{C. $M P P T$}

MPPT adalah sebuah program dimana pengaplikasiannya untuk mendapatkan tegangan dan arus maksimum dari sebuah panel surya sehingga daya keluaran dari panel surya agar losis daya yang terjadi yakni hilang susut daya yang terjadi. 


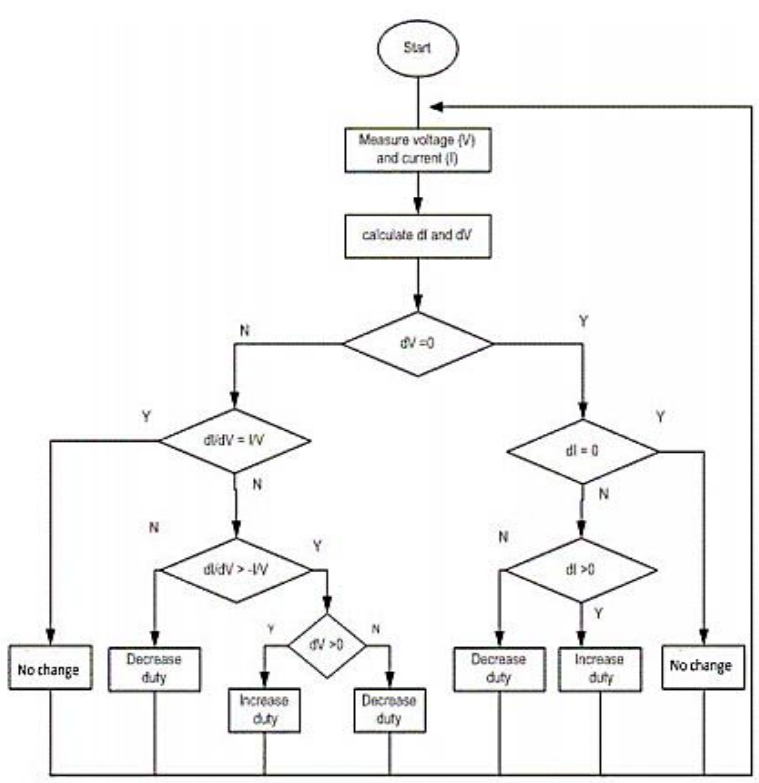

Gambar 3. MPPT Incremental Conductace

Dalam Gambar 3, untuk mencapai MPPT sebuah panel surya yaitu tidak adanya perubahan nilai arus dan tegangan pada sistem dan juga bisa ditandai dengan perbandingan besarnya perubahan arus dibagi perubahan tegangan akan sama dengan nilai perbandingan arus dan tegangannya[4].

\section{PID}

Kontrol PID merupakan kontroler berumpan balik yang terdiri atas kombinasi kontrol P, kontrol I, dan kontrol D yang memiliki tujuan mengkontrol hasil output, mempercepat reaksi kontrol, menghilangkan offset serta menghasilkan perubahan pada kondisi awal yang cukup besar yang ditampilkan dalam blok diagram pada Gambar 4[6].

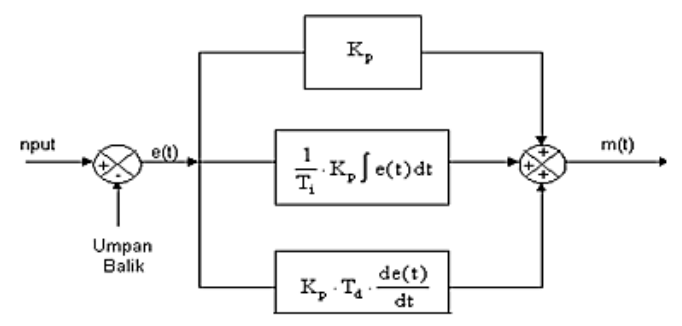

Gambar 4. Blok Diagram PID Analog

\section{METODE PENELITIAN}

Pada penelitian ini terdapat perencanaan sistem yaitu pembuatan blok diagram sistem. Blok diagram sistem digambarkan seperti pada Gambar 5.

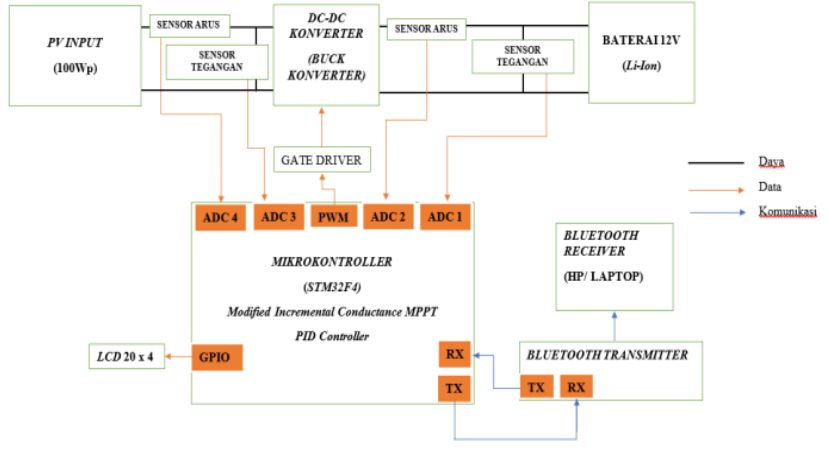

Gambar 5. Blok Diagram Sistem

Pada penelitian ini menggunakan sebuah $P V$ dengan daya max sebesar $100 \mathrm{Wp}$. Tegangan keluaran $P V$ yang masih fluktuatif dipengaruhi oleh besarnya intensitas cahaya dan suhu lingkungan, maka diperlukan $D C-D C$ konverter untuk menstabilkan tegangan output $P V$ dengan bantuan kontrol. Pada penelitian ini digunakan konverter jenis buck dan kontrolnya menggunakan $P W M$ berjenis $M P P T$ dengan metode modified incremental conductance dan kontrol PID analitik. Baterai Li-Ion digunakan sebagai penyimpanan energi dari $P V$ yang telah melewati konverter dengan tegangan nominal 10,8V. Sebagai media interface digunakanlah LCD $20 \times 4$ serta STM32F4 sebagai mkrokontrolernya. Pada penelitian ini juga dilakukan perencanaan baik hardware maupun kontrol.

\section{A. Perencanaan Photovoltaic}

Dalam penelitian ini akan digunakan 1 buah photovoltaic SUN ASIA 100 WP. Dengan spesifikasi pada Tabel 1 berikut :

Tabel 1. Spesifikasi Photovoltaic

\begin{tabular}{lc}
\hline \multicolumn{1}{c}{ Karakteristik } & Nilai \\
\hline Maximum Power (Pmax) & $100 \mathrm{~W}$ \\
\hline Power Tolerance & $+3 \%$ \\
\hline Maximum Power Voltage (Vmp) & $17.80 \mathrm{~V}$ \\
\hline Maximum Power Current (Imp) & $5.62 \mathrm{~A}$ \\
\hline Open Circuit Voltage (Voc) & $21.80 \mathrm{~V}$ \\
\hline Short Circuit Current (Isc) & $6.05 \mathrm{~A}$ \\
\hline
\end{tabular}

\section{B. Perencanaan Buck Converter}

Jenis konverter yang digunakan pada penelitian ini adalah buck converter dengan perencanaan sesuai parameter[1].

\section{Parameter :}


Vin $\min =13 \mathrm{~V} ;$ Vin $\max =21 \mathrm{~V} ; \mathrm{Vo}=12,6 \mathrm{~V} ; \mathrm{Io}$

$=8 \mathrm{~A} ; \mathrm{F}=40 \mathrm{kHz} ; \Delta i L=20 \% x i L ; r V o=0,5 \%$

$x$ Vo

Desain :

1. Duty Cycle

$$
D=\frac{V o}{V s}=\frac{12.6}{21}=0.6
$$

2. Resistor

$$
R=\frac{V o}{I o}=\frac{12.6}{8}=1.575 \Omega
$$

\section{Nilai Induktor}

$$
\begin{aligned}
& I L=I o=8 A \\
& \Delta I L=20 \% x I L=0,2 \times 6=1,6 A \\
& L=\frac{\operatorname{Vox}(1-D)}{\Delta I L x f} \\
& L=\frac{12,6 x(1-0,6)}{1,6 \times 40000} \\
& L=0,00007875 \mathrm{H}=78,75 \mu \mathrm{H}
\end{aligned}
$$

\section{Nilai Capasitor}

$$
\begin{aligned}
r & =0.5 \% \\
\mathrm{C} & =\frac{(1-\mathrm{D})}{8 \times \operatorname{Lxrxf}^{2}} \\
& =\frac{(1-0,6)}{8 \times 78,75 \times 10^{-6} \times 0,005 \times 40000^{2}} \\
& =79,36 \mu \mathrm{F} \\
& =80 \mu \mathrm{F}
\end{aligned}
$$

\section{Perencanaan Baterai}

Dalam perancanaan ini jenis baterai yang digunakan adalah Li-Ion dengan nomor model Samsung SDI-INR18650-35E [2]. Dengan spesifikasi pada Tabel 2 berikut:

Tabel 2. Spesifikasi Baterai

\begin{tabular}{lc}
\hline \multicolumn{1}{c}{ Item } & Spesifikasi \\
\hline Kapasitas & $3350 \mathrm{mAh}$ \\
\hline Tegangan Charging & $4,2 \mathrm{~V}$ \\
\hline Tegangan Nominal & $3,6 \mathrm{~V}$ \\
\hline Metode Charging & $\mathrm{CC}-\mathrm{CV}$ \\
\hline Arus Charging & $1 \mathrm{~A}-1,7 \mathrm{~A}$ \\
\hline Waktu Charging & $4 \mathrm{Jam}$ \\
\hline Arus Charging Maksimum & $2 \mathrm{~A}$ \\
\hline Arus Discharge Maksimum & $8 \mathrm{~A}$ \\
\hline Tegangan Cut-Off Discharge & $2,65 \mathrm{~V}$ \\
\hline
\end{tabular}

Dari Tabel 2, mengenai baterai akan dirakit dengan konfigurasi 3 seri dan 4 paralel (3S4P) dimana nantinya baterai memiliki kapasitas $13,4 \mathrm{Ah}$. Dari data tersebut, maka tegangan keluaran konverter maksimum yang dapat diberikan pada baterai adalah sebesar $12,6 \mathrm{~V}$ dikarenakan pada percobaan kali ini digunakan konfigurasi baterai 3 seri sehingga tegangan maksimum pengisian adalah sebesar $12,6 \mathrm{~V}$ (4,2 x 3 cell) dengan dibantu oleh modul BMS agar pengisian dapat seimbang setiap cell nya.

\section{Perencanaan Kontrol PID}

Pada penelitian ini digunakan PID dengan perhitungan $\mathrm{Kp}$, Ki dan Kd nya menggunakan metode analitik. Yang mula mula diambil grafik respon buck konverter dimana masih terdapat overshoot pada sistem seperti yang terlihat pada Gambar 6.

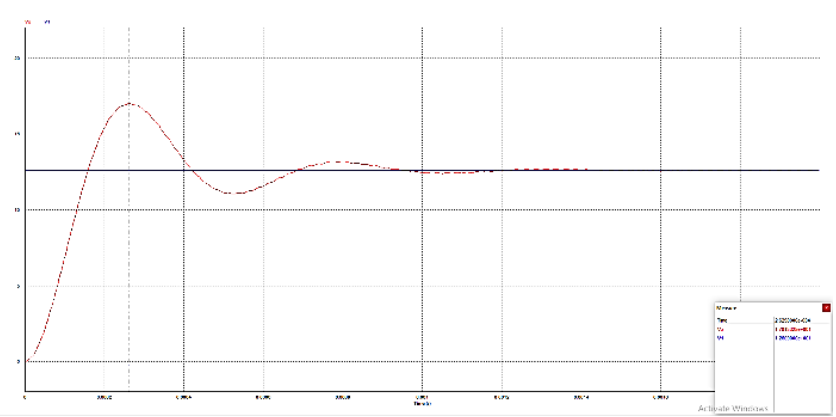

Gambar 6. Gelombang Respon Buck Converter

Diketahui :

$$
\begin{aligned}
& -\mathrm{ts}=10^{-3} \mathrm{~s} \\
& -\mathrm{tp}=2,63 \times 10^{-4} \mathrm{~s} \\
& -\mathrm{Vp}=17,01 \mathrm{~V} \\
& - \text { Set Point }=12,6 \mathrm{~V} \\
& - \text { Steady Response }=12,6 \mathrm{~V} \\
* K= & \frac{Y s s}{X s s}=\frac{12,6}{12,6}=1 \\
* \tau= & \frac{1}{5} x t s=\frac{1}{5} \times 10^{-2}=0,2 \times 10^{-3} s \\
* \alpha= & \frac{1}{\tau}=\frac{1}{0,2 \times 10^{-3}}=5000 / s^{-3} \\
* \omega d= & \frac{\pi}{t p}=\frac{3,14}{2,63 \times 10^{-3}} \\
= & 11939,16 \mathrm{rad} / \mathrm{sec}
\end{aligned}
$$




$$
\begin{aligned}
& * \omega d \quad=\omega n \sqrt{1-\xi^{2}} \\
& 1193,16=\frac{5000}{\xi}{\sqrt{1-\zeta^{2}}}^{2} \\
& 142543541,51=\frac{25000000}{\xi^{2}}\left(1-\xi^{2}\right) \\
& 142543541.51 \xi^{2}=25000000-25000000 \xi^{2} \\
& 167543541.51 \xi^{2}=25000000 \\
& \xi^{2}=0,15 \\
& \xi=0,39 \\
& * \omega n=\frac{\alpha}{\xi}=\frac{5000}{0,39}=12820,51
\end{aligned}
$$

Sehingga OLTF :

$$
\begin{aligned}
* & \frac{C(S)}{u(S)}=\frac{k \omega n^{2}}{S^{2}+2 \xi \omega n S+\omega n^{2}} \\
& =\frac{1 \chi 12820,51^{2}}{S^{2}+2 \chi 0,39 \chi 12820,51 S+12820,51^{2}} \\
& =\frac{164365476,66}{S^{2}+10000 S+164365476,66}
\end{aligned}
$$

$$
=\frac{1}{6,08 \times 10^{-5} \times 12820,51}=10^{-4} s
$$

Saat dipercepat (10x):

$$
\begin{aligned}
& * t s=10^{-3} s \\
& * t s=10^{-4} s \\
& * \tau^{\bullet}=\frac{1}{5} t s^{\bullet}=0,2 \times 10^{-4} s \\
& * K P=\frac{\tau i}{k \tau^{\bullet}}=\frac{6,08 \times 10^{-5}}{0,2 \times 10^{-4}}=3,04 \\
& * K I=\frac{K P}{\tau i}=\frac{3,04}{6,08 \times 10^{-5}}=50000 \\
& * K D=K P \times \tau d=3,04 \times 10^{-4}
\end{aligned}
$$

Berikut adalah gelombang setelah diberikan kontrol PID :

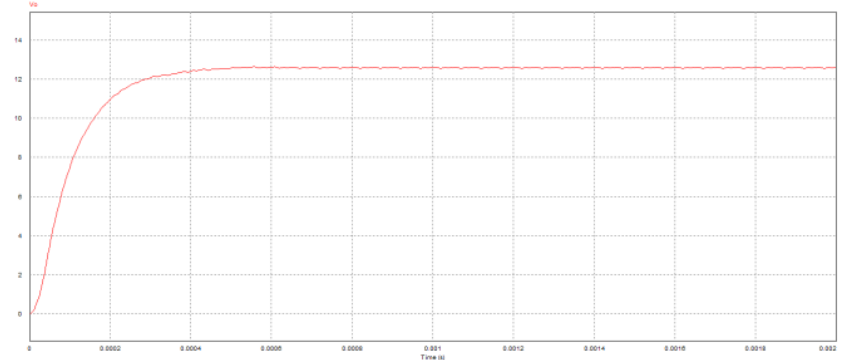

Gambar 7. Gelombang Respon Buck Converter Setelah PID

Dari Gambar 7 dapat diketahui bahwa kontrol PID dapat menghilangkan overshoot yang terjadi sehingga hingga menuju steady state tanpa terjadi overshoot. Untuk mempercepat waktu steady state maka dilakukan juga tuning pada PID dengan nilai yang didapat sebagai berikut :

$$
\begin{aligned}
& * K P=7,8 \\
& * K I=50000 \\
& * K D=0,000304
\end{aligned}
$$

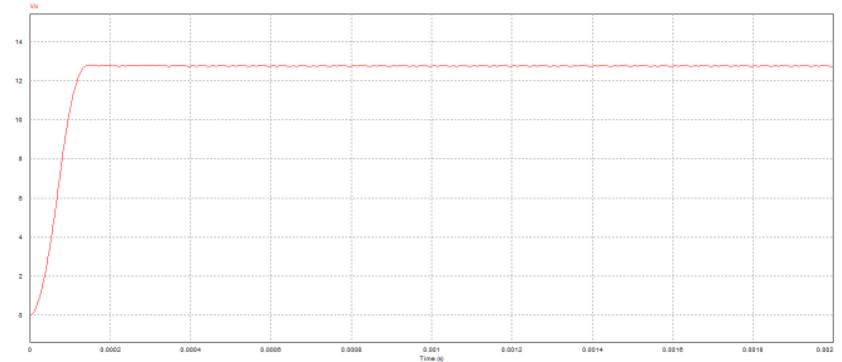

Gambar 8. Gelombang Respon Buck Converter Setelah Tuning PID

Dari Gambar 8 diketahui tuning PID akan berimbas pada semakin cepatnya respon steady state yang didapat. Dimana pada sebelum di tuning memiliki respon steady state sebesar $0,6 \mathrm{~ms}$ setelah di tuning respon yang didapat yaitu semakin cepat menjadi $0,16 \mathrm{~ms}$.

\section{E. Perencanaan MPPT}

MPPT yang digunakan dalam penelitian ini menggunakan metode modified incremental conductance yang berguna sebagai tracking sehingga panel surya dapat mengeluarkan daya maksimum yang dimiliki[4]. Alasan digunakannya metode tersebut yaitu dengan metode tersebut memiliki proses deteksi tracking sangat detail sehingga osilasi daya yang dikeluarkan oleh panel surya akan kecil atau bisa dikatakan lebih teliti. Flowchart algoritma MPPT 
Jurnal ECOTIPE, Volume 8, No.2, Oktober 2021, Hal. 120-130

p-ISSN 2355-5068, e-ISSN 2622-4852

Akreditasi Kemenristekdikti (SINTA 4), SK. No.10/E/KPT/2019

DOI: 10.33019/jurnalecotipe.v8i2.2560

metode modified incremental conductance adalah sebagai berikut :

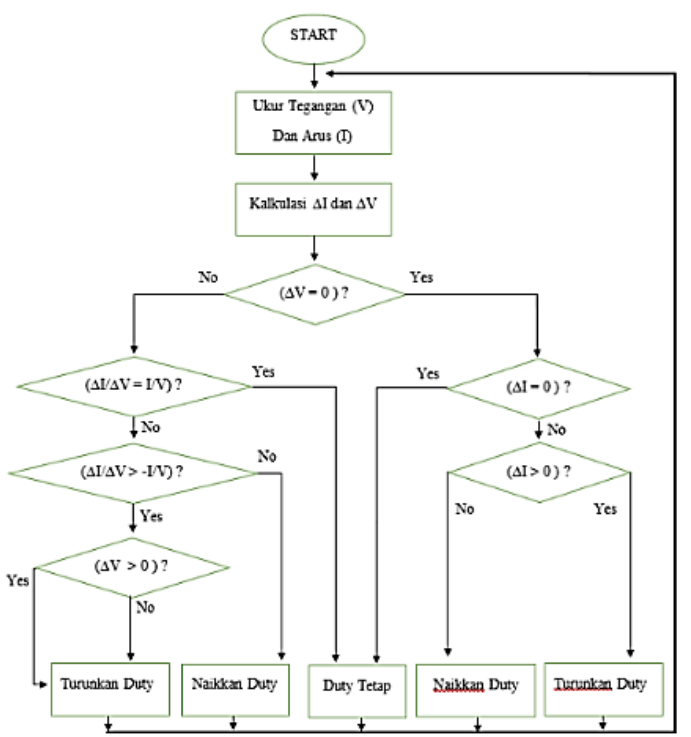

Gambar 9. Algoritma MPPT Metode Modified Incremenal Conductance

Dari Gambar 9, didapati bahwa panel surya telah mencapai daya maksimumnya saat tidak adanya perubahan nilai arus yang terjadi dan nilai perbandingan antara perubahan arus terhadap perubahan tegangannya sama dengan nilai perbandingan antara arus terhadap tegangannya.

\section{HASIL PENELITIAN DAN PEMBAHASAN}

Didalam hasil dan pembahasan ini memiliki beberapa pengujian sebagai berikut:

A. Pengujian Karakteristik PV

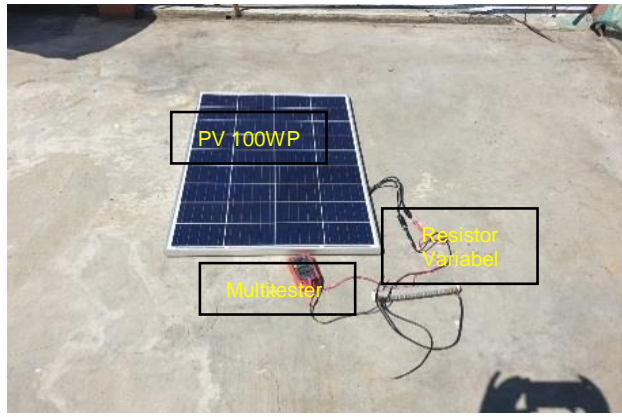

Gambar 10. Dokumentasi Pengujian Karakteristik $P V$

Seperti Gambar 10, Pengujian $P V$ dilakukan untuk mengetahui karakteristik panel terhadap paparan sinar matahari. Pengujian dilakukan pada tanggal 6-Juni-2021 berlokasikan di Jl. Tenggumung Wetan GG. Rambutan 07, pada pukul 10:00-14:00.

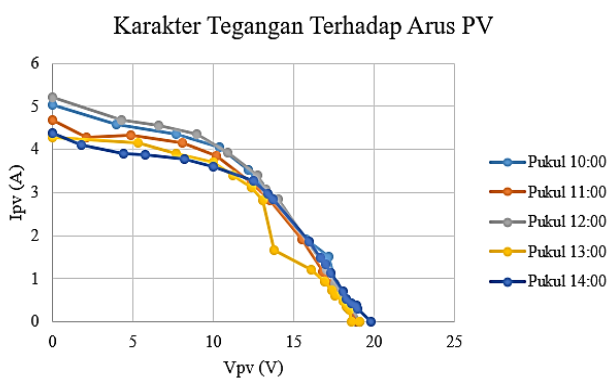

Gambar 11. Grafik Karakter Tegangan Terhadap Arus $P V$

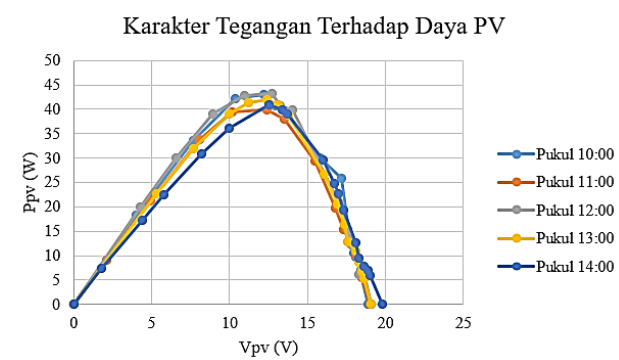

Gambar 12. Grafik Karakter Tegangan Terhadap Daya $P V$

Dari Gambar 11 dan 12 diketahui daya yang mampu dihasilkan oleh $P V$ yaitu berkisar antara 15$45 \mathrm{~W}$ sedangkan untuk tegangannya berkisar 10-19V.

\section{B. Pengujian Buck Converter}

Pengujian buck converter pada Gambar 13 dengan perubahan duty cycle dari 10\% hingga 90\% menggunakan sebuah power supply DC dengan menyamakan deangan keadaan $P V$ maka buck converter diuji pada beberapa tegangan untuk memastikan buck converter dapat bekerja pada $P V$. Percobaan ini diambil pada tegangan input berbeda, namun yang tersaji dalam tabel yaitu pengujian dengan tegangan input sebesar $13 \mathrm{~V}, 17 \mathrm{~V}$, dan $21 \mathrm{~V}$ pada Tabel 3, 4 dan 5 .

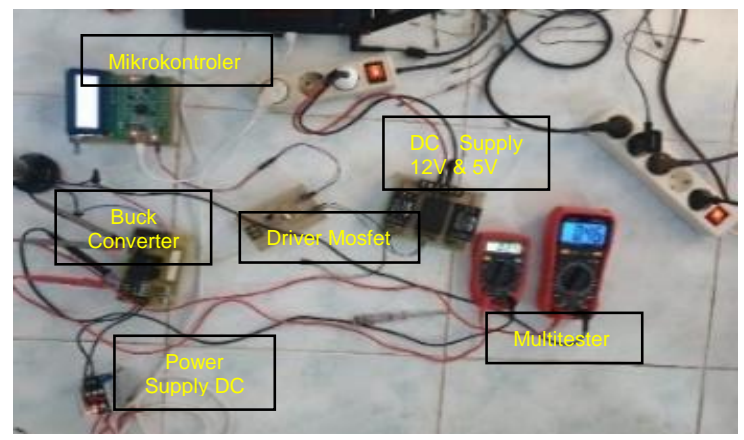

Gambar 13. Dokumentasi Pengujian Buck Converter 
Jurnal ECOTIPE, Volume 8, No.2, Oktober 2021, Hal. 120-130

p-ISSN 2355-5068, e-ISSN 2622-4852

Akreditasi Kemenristekdikti (SINTA 4), SK. No.10/E/KPT/2019

DOI: 10.33019/jurnalecotipe.v8i2.2560

Tabel 3. Uji Buck dengan Tegangan Uji 13V

\begin{tabular}{|c|c|c|c|c|c|c|c|c|c|}
\hline \multirow{2}{*}{$\begin{array}{l}\text { Vin } \\
\text { (V) }\end{array}$} & \multirow{2}{*}{$\underset{(\%)}{D}$} & \multicolumn{2}{|c|}{ Vo $(V)$} & \multirow{2}{*}{ Io } & \multirow{2}{*}{$\begin{array}{l}\text { Iin } \\
\text { (A) }\end{array}$} & \multirow{2}{*}{$\begin{array}{l}\text { Po } \\
\text { (W) }\end{array}$} & \multirow{2}{*}{$\begin{array}{c}\mathbf{P i} \\
(\mathbf{W})\end{array}$} & \multirow{2}{*}{$\begin{array}{c}\text { Eff } \\
(\%)\end{array}$} & \multirow{2}{*}{$\begin{array}{l}\text { Error } \\
(\%)\end{array}$} \\
\hline & & Teori & Prak & & & & & & \\
\hline 13 & 10 & 1,3 & 1,28 & 0,09 & 0,01 & 0,12 & 0,13 & 88,62 & 1,54 \\
\hline 13 & 20 & 2,6 & 2,7 & 0,18 & 0,04 & 0,49 & 0,52 & 93,46 & 3,85 \\
\hline 13 & 30 & 3,9 & 4,15 & 0,24 & 0,08 & 1,00 & 1,04 & 95,77 & 6,41 \\
\hline 13 & 40 & 5,2 & 5,51 & 0,28 & 0,13 & 1,54 & 1,69 & 91,29 & 5,96 \\
\hline 13 & 50 & 6,5 & 6,55 & 0,3 & 0,16 & 1,97 & 2,08 & 94,47 & 0,77 \\
\hline 13 & 60 & 7,8 & 7,55 & 0,32 & 0,2 & 2,42 & 2,6 & 92,92 & 3,21 \\
\hline 13 & 70 & 9,1 & 8,9 & 0,35 & 0,25 & 3,12 & 3,25 & 95,85 & 2,20 \\
\hline 13 & 80 & 10,4 & 10,27 & 0,37 & 0,3 & 3,80 & 3,9 & 97,43 & 1,25 \\
\hline 13 & 90 & 11,7 & 11,65 & 0,38 & 0,36 & 4,43 & 4,68 & 94,59 & 0,43 \\
\hline
\end{tabular}

Tabel 4. Uji Buck dengan Tegangan Uji 17V

\begin{tabular}{cccccccccc}
\multirow{2}{*}{$\begin{array}{l}\text { Vin } \\
(\mathbf{V})\end{array}$} & $\begin{array}{c}\text { D } \\
(\boldsymbol{\%})\end{array}$ & \multicolumn{2}{c}{ Vo $(\mathbf{V})$} & Io & $\begin{array}{c}\text { Iin } \\
(\mathbf{A})\end{array}$ & $\begin{array}{c}\text { Po } \\
(\mathbf{W})\end{array}$ & $\begin{array}{c}\text { Pi } \\
(\mathbf{W})\end{array}$ & $\begin{array}{c}\text { Eff } \\
(\boldsymbol{\%})\end{array}$ & $\begin{array}{c}\text { Error } \\
(\boldsymbol{\%})\end{array}$ \\
\cline { 3 - 8 } & & Teori & Prak & & & & & & \\
\hline $\mathbf{1 7}$ & 10 & 1,7 & 1,53 & 0,14 & 0,01 & 0,21 & 0,25 & 84 & 10 \\
\hline $\mathbf{1 7}$ & 20 & 3,4 & 3,34 & 0,25 & 0,06 & 0.84 & 1,02 & 81,86 & 1,76 \\
\hline $\mathbf{1 7}$ & 30 & 5,1 & 5,4 & 0,33 & 0,11 & 1,73 & 1,87 & 92,47 & 2,75 \\
\hline $\mathbf{1 7}$ & 40 & 6,8 & 7 & 0,38 & 0,17 & 2,66 & 2,89 & 92,04 & 2,94 \\
\hline $\mathbf{1 7}$ & 50 & 8,5 & 8,39 & 0,41 & 0,22 & 3,44 & 3,74 & 91,98 & 1,29 \\
\hline $\mathbf{1 7}$ & 60 & 10,02 & 9,93 & 0,44 & 0,27 & 4,37 & 4,59 & 95,19 & 2,65 \\
\hline $\mathbf{1 7}$ & 70 & 11,9 & 11,69 & 0,47 & 0,34 & 5,49 & 5,78 & 95,06 & 1,76 \\
\hline $\mathbf{1 7}$ & 80 & 13,6 & 13,46 & 0,49 & 0,4 & 6,60 & 6,8 & 96,99 & 1,03 \\
\hline $\mathbf{1 7}$ & 90 & 15,25 & 15,25 & 0,51 & 0,47 & 7,78 & 7,99 & 97,34 & 0,33 \\
\hline & & & & & & & &
\end{tabular}

Tabel 5. Uji Buck dengan Tegangan Uji 21V

\begin{tabular}{|c|c|c|c|c|c|c|c|c|c|}
\hline \multirow{2}{*}{$\begin{array}{l}\text { Vin } \\
\text { (V) }\end{array}$} & \multirow{2}{*}{$\underset{(\%)}{\mathrm{D}}$} & \multicolumn{2}{|c|}{ Vo $(\mathbf{V})$} & \multirow{2}{*}{$\begin{array}{l}\text { Io } \\
\text { (A) }\end{array}$} & \multirow{2}{*}{$\begin{array}{l}\text { Iin } \\
\text { (A) }\end{array}$} & \multirow{2}{*}{$\begin{array}{c}\text { Po } \\
\text { (W) }\end{array}$} & \multirow{2}{*}{$\begin{array}{c}\mathbf{P i} \\
(\mathbf{W})\end{array}$} & \multirow{2}{*}{$\begin{array}{r}\text { Eff } \\
(\%)\end{array}$} & \multirow{2}{*}{$\begin{array}{c}\text { Error } \\
(\%)\end{array}$} \\
\hline & & Teori & & & & & & & \\
\hline 21 & 10 & 2,1 & 1,84 & 19 &, 02 & 0,3 & 0,42 & 83,24 & 12,38 \\
\hline 21 & 20 & 4,2 & 4,06 & 0,33 &, 07 & 1,34 & 1,47 & 91,14 & 3,33 \\
\hline 21 & 30 & 6,3 & 6,43 & 0,42 &, 14 & & 2,9 & 91,86 & 2,06 \\
\hline 21 & 40 & 8,4 & 8,62 & 0,48 & 0,21 & 4,14 & 4,41 & 93,82 & 2,62 \\
\hline 21 & 50 & 10,5 & 10,4 & 0,52 & 0,27 & 5,41 & 5,67 & 95,38 & 0,95 \\
\hline 21 & 60 & 12,6 & 12,36 & 0,55 & 0,35 & 6,80 & 7,35 & 92,49 & 1,90 \\
\hline 21 & 70 & 14,7 & 14,52 & 0,58 & 0,42 & 8,42 & 8,82 & 95,48 & 1,22 \\
\hline 21 & 80 & 16,8 & 16,7 & 0,61 & 0,51 & 10,1 & 10,7 & 95,12 & 0,6 \\
\hline 21 & 90 & 18,9 & 18,9 & 0,64 & 0,6 & 12,1 & 12,6 & 95 & 0 \\
\hline
\end{tabular}

Dari Tabel 3, 4, dan 5 diketahui bahwa masih terjadi error dan juga effisiensi nya masih belum $100 \%$ hal ini dikarenakan ketidaktepatan komponen maupun alat ukur yang dipakai.

\section{Pengujian Performa Baterai}

Pada pengujian performa baterai, akan dilakukan menggunakan buck konverter yang telah dibuat dan dengan sumber sebuah power supply untuk mengetahui waktu pengisian dan juga kemampuan baterai saat di charging dengan daya maksimum PV yaitu sebesar 100W. Berikut adalah dokumentasi pengujian pada Gambar 14.

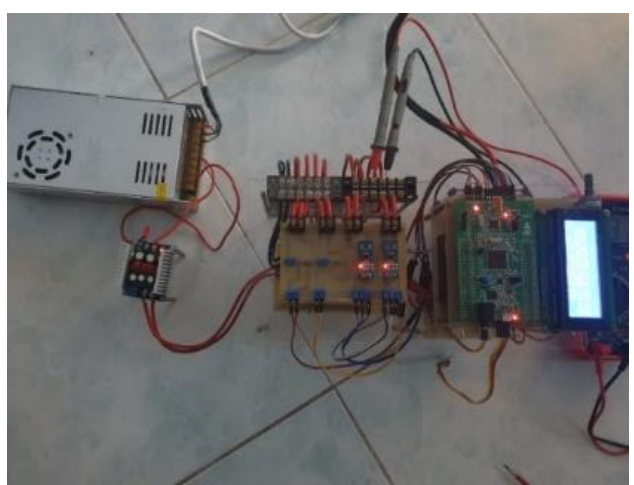

Gambar 14. Dokumentasi Pengujian Baterai

Dari pengujian yang telah dilakukan didapati data pada Tabel 6.

Tabel 6. Uji Performa Baterai

\begin{tabular}{|c|c|c|c|}
\hline Detik-Ke & Vch (V) & Ich (A) & $\operatorname{Pch}(W)$ \\
\hline 1 & 10.3 & 3 & 30.9 \\
\hline 2 & 11.1 & 5 & 55.5 \\
\hline 3 & 11.95 & 7.84 & 93.688 \\
\hline 4 & 11.95 & 7.54 & 90.103 \\
\hline 5 & 12.16 & 8 & 97.28 \\
\hline 6 & 12.16 & 7.96 & 96.7936 \\
\hline 126 & 12.24 & 8 & 97.92 \\
\hline 186 & 12.24 & 7.9 & 96.696 \\
\hline 187 & 12.35 & 8 & 98.8 \\
\hline 247 & 12.36 & 7.95 & 98.262 \\
\hline 307 & 12.35 & 8 & 98.8 \\
\hline 367 & 12.4 & 7.9 & 97.96 \\
\hline 368 & 12.4 & 8 & 99.2 \\
\hline 488 & 12.42 & 8.05 & 99.981 \\
\hline 548 & 12.39 & 7.87 & 97.5093 \\
\hline 549 & 12.45 & 7.95 & 98.9775 \\
\hline 669 & 12.48 & 8 & 99.84 \\
\hline 729 & 12.48 & 7.98 & 99.5904 \\
\hline 789 & 12.53 & 7.9 & 98.987 \\
\hline 790 & 12.55 & 7.9 & 99.145 \\
\hline 860 & 12.6 & 7.8 & 98.28 \\
\hline 1460 & 12.6 & 7 & 88.2 \\
\hline 2060 & 12.6 & 6.45 & 81.27 \\
\hline 2660 & 12.6 & 5.77 & 72.702 \\
\hline 3260 & 12.6 & 5.13 & 64.638 \\
\hline 3860 & 12.6 & 4.51 & 56.826 \\
\hline 4460 & 12.6 & 4.01 & 50.526 \\
\hline
\end{tabular}


Jurnal ECOTIPE, Volume 8, No.2, Oktober 2021, Hal. 120-130

p-ISSN 2355-5068, e-ISSN 2622-4852

Akreditasi Kemenristekdikti (SINTA 4), SK. No.10/E/KPT/2019

DOI: 10.33019/jurnalecotipe.v8i2.2560

Lanjutan Tabel 6

\begin{tabular}{cccc}
\hline Detik-Ke & Vch $(\mathbf{V})$ & Ich $(\mathbf{A})$ & Pch $(\mathbf{W})$ \\
\hline $\mathbf{5 0 6 0}$ & 12.6 & 3.52 & 44.352 \\
\hline $\mathbf{5 6 6 0}$ & 12.6 & 3.22 & 40.572 \\
\hline $\mathbf{6 2 6 0}$ & 12.6 & 2.77 & 34.902 \\
\hline $\mathbf{6 8 6 0}$ & 12.6 & 2.52 & 31.752 \\
\hline $\mathbf{7 4 6 0}$ & 12.6 & 2.09 & 26.334 \\
\hline $\mathbf{8 0 6 0}$ & 12.6 & 1.82 & 22.932 \\
\hline $\mathbf{8 6 6 0}$ & 12.6 & 1.54 & 19.404 \\
\hline $\mathbf{9 2 6 0}$ & 12.6 & 1.31 & 16.506 \\
\hline $\mathbf{9 8 6 0}$ & 12.6 & 1.2 & 15.12 \\
\hline $\mathbf{1 0 4 6 0}$ & 12.6 & 1 & 12.6 \\
\hline
\end{tabular}

Dari Tabel 6 didapati bahwa, baterai di charging hingga penuh dengan perpaduan antara charging dengan daya mendekati $100 \mathrm{~W}$ dan tegangan konstan memerlukan waktu 10460 detik atau sekitar 2,9 jam. dan dari percobaan ini didapati bahwa baterai mampu di charging dengan daya sebesar daya maksimum panel surya yaitu sebesar 100W sehingga dapat dipastikan dapat berjalan dengan normal saat diterapkan.

\section{Pengujian MPPT}

Pengujian MPPT dengan metode modified incremental conductance yang dilakukan dengan bantuan software PSIM. Untuk parameter radiasi diatur berubah-ubah dengan nilai $100-1000 \mathrm{~W} / \mathrm{m}^{2}$ dengan step $100 \mathrm{~W} / \mathrm{m}^{2}$ serta dengan temperature $25^{\circ} \mathrm{C}$.

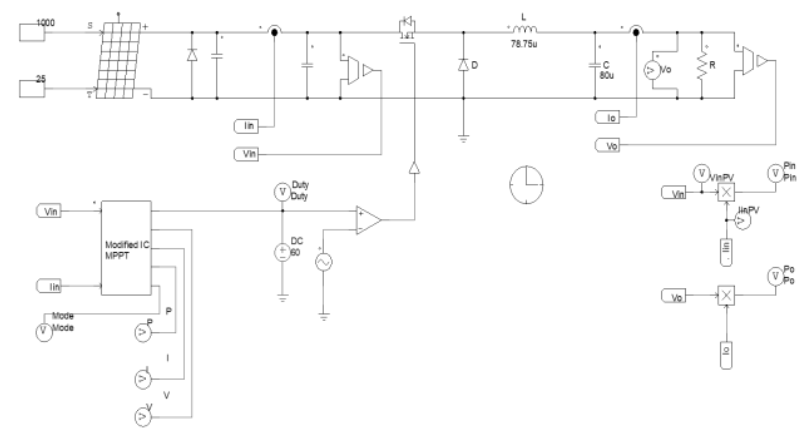

Gambar 15. Rangkaian MPPT pada Software PSIM

Pada Gambar 15 didapati bahwa pada sistem ini menggunakan sebuah $P V$ berspesifikasi $100 \mathrm{Wp}$ dan konverter yang digunakan merupakan buck converter. Berdasarkan hasil simulasi didapat data tracking seperti yang ditunjukkan dengan data tersaji pada Tabel 7.
Tabel 7. Data Uji MPPT Iradiasi Konstan

\begin{tabular}{cccccc}
\hline $\begin{array}{c}\mathbf{I} \\
\begin{array}{c}\text { Radiance } \\
\left(\mathbf{W} / \mathbf{m}^{2}\right)\end{array}\end{array}$ & $\begin{array}{c}\mathbf{V p v} \\
(\mathbf{V})\end{array}$ & $\begin{array}{c}\text { Ipv } \\
(\mathbf{A})\end{array}$ & $\begin{array}{c}\text { Ppv } \\
(\mathbf{W})\end{array}$ & $\begin{array}{c}\text { Pmax } \\
(\mathbf{W})\end{array}$ & $\begin{array}{c}\text { Akurasi } \\
(\%)\end{array}$ \\
\hline $\mathbf{1 0 0}$ & 15,8 & 0,56 & 8,85 & 8,91 & 99,30 \\
\hline $\mathbf{2 0 0}$ & 16,53 & 1,12 & 18,51 & 18,62 & 99,43 \\
\hline $\mathbf{3 0 0}$ & 16,93 & 1,68 & 28,44 & 28,57 & 99,55 \\
\hline $\mathbf{4 0 0}$ & 17,09 & 2,26 & 38,64 & 38,66 & 99,94 \\
\hline $\mathbf{5 0 0}$ & 17,31 & 2,82 & 48,81 & 48,84 & 99,95 \\
\hline $\mathbf{6 0 0}$ & 17,33 & 3,4 & 58,92 & 59,04 & 99,80 \\
\hline $\mathbf{7 0 0}$ & 17,53 & 3,94 & 69,07 & 69,27 & 99,71 \\
\hline $\mathbf{8 0 0}$ & 17,58 & 4,52 & 79,46 & 79,52 & 99,93 \\
\hline $\mathbf{9 0 0}$ & 17,57 & 5,1 & 89,61 & 89,77 & 99,82 \\
\hline $\mathbf{1 0 0 0}$ & 17,76 & 5,63 & 99,99 & 99,99 & 100,00 \\
\hline
\end{tabular}

Berdasarkan Tabel 8, dari data tersebut maka dapat dikatakan bahwa MPPT telah berjalan dan dapat diterapkan pada sistem dimana $M P P T$ sudah dapat tracking daya maksimum dimana untuk range tegangan input yang diberikan oleh PV adalah $15,8 \mathrm{~V}$ hingga $17,76 \mathrm{~V}$. Dan dari segi akurasi $M P P T$ sudah dikatakan sangat baik karena hasil dari MPPT memiliki akurasi atau ketepatan dalam range $99.3 \%$ hingga $100 \%$. Dan setelah itu dilakukan pula pengamatan pada sisi konverter dengan hasil pada Tabel 8.

Tabel 8. Hasil Pengujian MPPT untuk Pengisian Baterai

\begin{tabular}{ccccc}
\hline $\begin{array}{c}\text { I Radiance } \\
\left(\mathbf{W} / \mathbf{m}^{2}\right)\end{array}$ & $\begin{array}{c}\text { Vout } \\
\text { Conv } \\
(\mathbf{V})\end{array}$ & $\begin{array}{c}\text { Iout } \\
\text { Conv } \\
(\mathbf{A})\end{array}$ & $\begin{array}{c}\text { Pout } \\
\text { Conv } \\
(\mathbf{W})\end{array}$ & $\begin{array}{c}\text { Duty } \\
(\boldsymbol{\%})\end{array}$ \\
\hline $\mathbf{1 0 0}$ & 3,7 & 2,35 & 8,70 & 22 \\
\hline $\mathbf{2 0 0}$ & 5,36 & 3,4 & 18,22 & 32 \\
\hline $\mathbf{3 0 0}$ & 6,67 & 4,24 & 28,28 & 40 \\
\hline $\mathbf{4 0 0}$ & 7,77 & 4,94 & 38,38 & 46 \\
\hline $\mathbf{5 0 0}$ & 8,74 & 5,54 & 48,42 & 50 \\
\hline $\mathbf{6 0 0}$ & 9,61 & 6,11 & 58,72 & 54 \\
\hline $\mathbf{7 0 0}$ & 10,43 & 6,62 & 69,05 & 58 \\
\hline $\mathbf{8 0 0}$ & 11,16 & 7,087 & 79,09 & 62 \\
\hline $\mathbf{9 0 0}$ & 11,86 & 7,53 & 89,31 & 66 \\
\hline $\mathbf{1 0 0 0}$ & 12,52 & 7,95 & 99,53 & 70 \\
\hline
\end{tabular}

Dari Tabel 8 didapati bahwa daya output konverter maksimum yaitu saat nilai iradiasi sebesar $1000 \mathrm{~W} / \mathrm{m}^{2}$. Dimana daya yang dikeluarkan konverter adalah $99,53 \mathrm{~W}$ dengan tegangan output konverter maksimum sebesar 12,52V dan dengan arus 7,95A.

Jenis baterai yang digunakan pada penelitian ini adalah Li-Ion Samsung SDI-INR18650-35E dengan konfigurasi 3S4P (3 Seri 4 Paralel) maka tegangan 
nominalnya menjadi $10,8 \mathrm{~V}$ dan tegangan pengisian maksimum 12,6V. Sehingga pada tabel dapat diketahui iradiasi minimum agar bisa melakukan pengisian adalah $800 \mathrm{~W} / \mathrm{m}^{2}$ dimana tegangan output konverter adalah sebesar 11,16V.

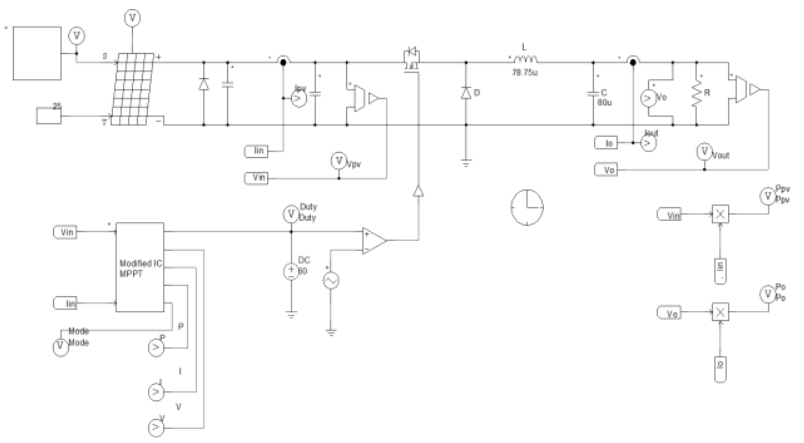

Gambar 16. Rangkaian Pengujian Performa MPPT pada Software PSIM

Seperti pada Gambar 16, Pengujian ini untuk mengetahui performa MPPT metode modified incremental conductance pada saat diterapkan pada kondisi iradiasi yang berubah secara tiba-tiba, baik dari tingkat iradiasi tinggi ke rendah ataupun sebaliknya. Proses tracking pada saat dilakukan pengujian yaitu dengan melakukan perubahan pada nilai iradiasi dengan perubahan $800-1000-500-$ $700 \mathrm{w} / \mathrm{m}^{2}$ dan dengan temperature $25^{\circ} \mathrm{C}$.

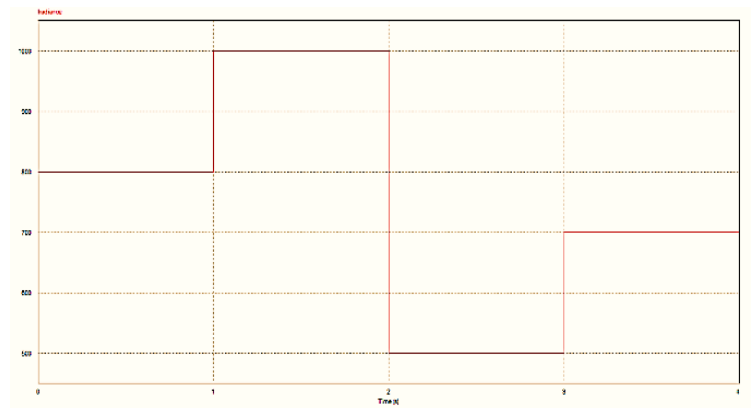

Gambar 17. Perubahan Nilai Iradiasi yang dilakukan

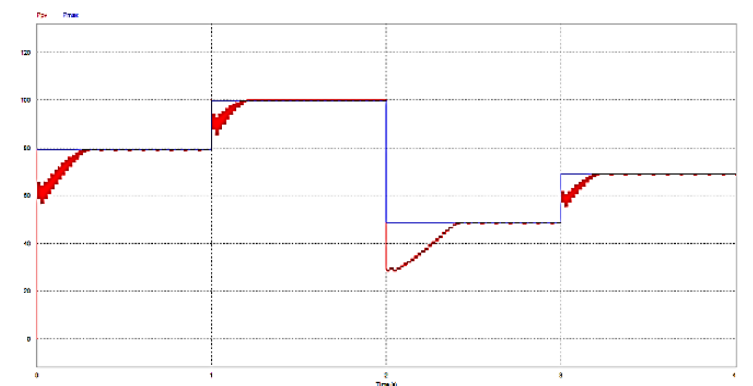

Gambar 18. Proses Tracking dari Iradiasi $800 \mathrm{~W} / \mathrm{m} 2 \mathrm{ke}$ $1000 \mathrm{~W} / \mathrm{m} 2 \mathrm{ke} 500 \mathrm{~W} / \mathrm{m} 2 \mathrm{ke} 700 \mathrm{~W} / \mathrm{m} 2$
Pada Gambar 17 dan 18 diketahui bahwa proses tracking daya dari iradiasi rendah ke tinggi ataupun sebaliknya dapat berjalan dengan baik. MPPT modified incremental conductance dapat menunjukkan performa yang baik dengan berhasil melakukan tracking ulang ketika ada perubahan iradiasi. Tracking dan penurunan drastis terjadi pada iradiasi 1000 menuju ke 500 yang memakan banyak waktu dikarenakan penurunan yang terlalu jauh hingga waktu akan mencapai daya maksimum sedikit lebih lambat.

\section{E. Pengujian PID}

Dikarenakan tegangan output konverter maksimum saat melakukan MPPT adalah $12,52 \mathrm{~V}$ sedangkan tegangan maksimum yang harus dicapai baterai adalah 12,6V digunakan kontrol PID metode analitk untuk mencapai serta menstabilkan tegangan pengisian baterai sehingga mencapai tegangan rating maksimumnya yang mana rangkaiannya ditampilkan dalam Gambar 19.

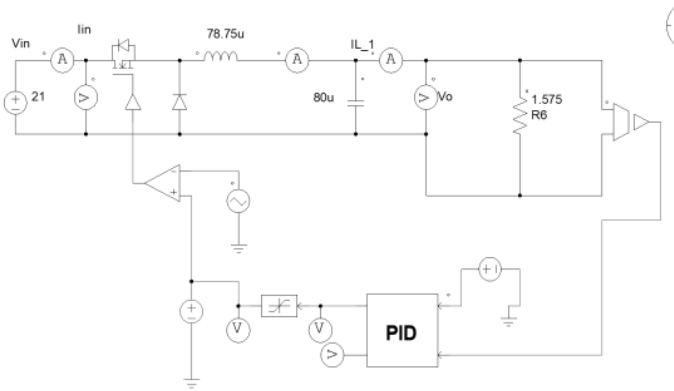

Gambar 19. Rangkaian PID pada Software PSIM

Tabel 9. Data Uji PID

\begin{tabular}{|c|c|c|c|c|c|c|c|}
\hline \\
\hline $\begin{array}{l}\text { Vin } \\
\text { (V) }\end{array}$ & $\begin{array}{l}\text { Iin } \\
\text { (A) }\end{array}$ & $\begin{array}{c}\text { Vout } \\
\text { (V) }\end{array}$ & $\begin{array}{l}\text { Iout } \\
\text { (A) }\end{array}$ & $\begin{array}{l}\text { Pin } \\
\text { (W) }\end{array}$ & $\begin{array}{c}\text { Pout } \\
(\mathbf{W})\end{array}$ & $\begin{array}{l}\text { Eff } \\
(\%)\end{array}$ & $\underset{(\%)}{D}$ \\
\hline 13 & 7,78 & 12,61 & 8,01 & 101,14 & 101,01 & 99,87 & 98 \\
\hline 14 & 7,21 & 12,6 & 8 & 100,94 & 100,80 & 99,86 & 92 \\
\hline 15 & 6,7 & 12,62 & 7,96 & 100,5 & 100,46 & 99,96 & 93 \\
\hline 16 & 6,33 & 12,61 & 8,02 & 101,28 & 101,13 & 99,85 & 87 \\
\hline 17 & 5,95 & 12,63 & 7,99 & 101,15 & 100,91 & 99,77 & 73 \\
\hline 18 & 5,6 & 12,64 & 7,96 & 100,8 & 100,61 & 99,82 & 70 \\
\hline 19 & 5,33 & 12,62 & 8,01 & 101,27 & 101,09 & 99,82 & 69 \\
\hline 20 & 5,05 & 12,65 & 7,95 & 101 & 100,57 & 99,57 & 66 \\
\hline 21 & 4,82 & 12,62 & 8,01 & 101,22 & 101,09 & 99,87 & 63 \\
\hline
\end{tabular}

Dari Tabel 9 didapati hasil output dari konverter sudah sesuai dengan setpoint yang dihasilkan yaitu 
Jurnal ECOTIPE, Volume 8, No.2, Oktober 2021, Hal. 120-130

p-ISSN 2355-5068, e-ISSN 2622-4852

Akreditasi Kemenristekdikti (SINTA 4), SK. No.10/E/KPT/2019

DOI: 10.33019/jurnalecotipe.v8i2.2560

sebesar $12,6 \mathrm{~V}$ sesuai rating yang tertera pada baterai. Namun pada hasil output konverter masih terjadi error dari sisi output konverter dimana error yang terjadi berkisar $0-0,05 \mathrm{~V}$ atau dalam persentase 0 $0,4 \%$. Untuk memastikan keandalan dari PID maka dilakukan pengujian dengan memberikan tegangan input yang berubah ubah dengan step naik dan turun dengan hasil berikut:

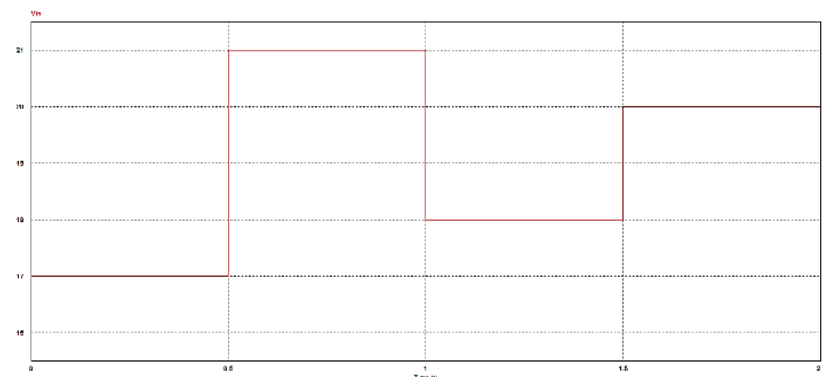

Gambar 20. Gambar Tegangan Input yang Diberikan dengan 17V dinaikkan 21V, dilakukan Penurunan 18V dan kenaikan $20 \mathrm{~V}$

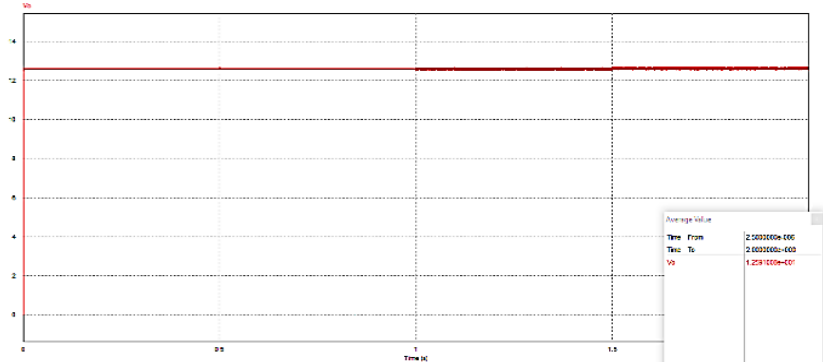

Gambar 21. Gambar Tegangan Output yang Diberikan dengan tegangan input $17 \mathrm{~V}$ dinaikkan $21 \mathrm{~V}$, dilakukan Penurunan $18 \mathrm{~V}$ dan kenaikan $20 \mathrm{~V}$

Dari hasil percobaan pada Gambar 20 dan 21 diketahui bahwa saat terjadi penurunan secara tiba tiba PID sudah siap dan handal. Dilihat dari hasil output yang telah mendekati set point yaitu $12,6 \mathrm{~V}$ pada pengujian kenaikan maupun penurunan tegangan input dan dapat dipastikan PID dapat mengikuti.

\section{KESIMPULAN}

Tracking maksimum MPPT metode Modified Incremental Conductance pada iradiasi $1000 \mathrm{~W} / \mathrm{m}^{2}$ dengan duty cycle $70 \%$ menghasilkan keluaran daya maksimum buck converter $99,53 \mathrm{~W}$ serta tegangan keluaran buck converter $12,52 \mathrm{~V}$ dan arus 7,95A. Kontrol PID dengan nilai parameter $\mathrm{Kp}=7,8$, $\mathrm{Ki}=50000$, dan $\mathrm{Kd}=0,000304$ digunakan untuk mendapatkan tegangan konstan keluaran dari buck converter sebesar 12,6V. Pada pengisian penuh baterai Li-Ion dengan daya pengisian sebesar 100W, diperlukan waktu 10460 detik.

\section{REFERENSI}

[1] Hart, Daniel W. (2011). Power Electronics. The McGraw Hill Companies. New York, Amerika.

[2] SDI, S. (2015). Inr 18650 - 35E. Retrieved from https://www.orbtronic.com/content/samsung-35edatasheet-inr18650-35e.pdf

[3] Haryadi S., G. R. F. S. (2016). Rancang Bangun Pemanfaatan Panel Surya Sebagai Charger Handphone Di Tempat Umum. Teknik Mesin UNISKA, 02(02), 114-120.

[4] Anowar, M. H., \& Roy, P. (2019). A Modified Incremental Conductance Based Photovoltaic MPPT Charge Controller. 2nd International Conference on Electrical, Computer and Communication Engineering, ECCE 2019,February.https://doi.org/10.1109/ECACE.2 019.8679308

[5] Prasetyono, E., Anggriawan, D. O., Firmansyah, A. Z., \& Windarko, N. A. (2017). A modified MPPT algorithm using incremental conductance for constant power generation of photovoltaic systems. Proceedings IES-ETA 2017 International Electronics Symposium on Engineering Technology and Applications, 2017December, https://doi.org/10.1109/ELECSYM.2017.824036 2

[6] N. T. Mooniarsih. (2016). Simulasi dan Analisis Kinerja Prediktor Smith pada Kontrol Proses yang Disertai Tundaan Waktu, Elkha, vol. 8, no. 2, pp. 6-13, 2016, doi: 10.26418/elkha.v8i2.18287.

[7] Thowil Afif, M., \& Ayu Putri Pratiwi, I. (2015). Analisis Perbandingan Baterai Lithium-Ion, Lithium-Polymer, Lead Acid dan Nickel-Metal Hydride pada Penggunaan Mobil Listrik Review. Jurnal Rekayasa Mesin, 6(2), 95-99. https://doi.org/10.21776/ub.jrm.2015.006.02.1

[8] Budhi Anto, Edy Hamdani, Rizki Abdullah. (2014). Portable Battery Charger Berbasis Sel 
Jurnal ECOTIPE, Volume 8, No.2, Oktober 2021, Hal. 120-130

p-ISSN 2355-5068, e-ISSN 2622-4852

Akreditasi Kemenristekdikti (SINTA 4), SK. No.10/E/KPT/2019

DOI: 10.33019/jurnalecotipe.v8i2.2560

Surya. Teknik Elektro Universitas Riau, Jurnal

Rekayasa Elektrika Vol. 11, No.1, April 2014, hal. 19-24

[9] Maranda, Witold. (2015). Capacity Degradation of Lead-acid Batteries Under Variable-depth Cycling Operation in Photovoltaic System. 10.1109/MIXDES.2015.7208584.

[10] Julisman, A., Sara, I. D., \& Siregar, R. H. (2017). Prototipe Pemanfaatan Panel Surya Sebagai Sumber Energi Pada Sistem Otomasi Stadion Bola. Jurnal Karya Ilmiah Teknik Elektro, 2(1), $35-42$. 